\title{
Associations between Bacteriophage Resistance and Antibiotic Resistance Phenotypes in Laboratory and Clinical strains of Salmonella Typhimurium
}

\section{Md Jalal Uddin}

Kangwon National University

Juhee Ahn ( $\sim$ Juheeahn@kangwon.ac.kr)

Kangwon National University https://orcid.org/0000-0001-9341-009X

\section{Research article}

Keywords: Bacteriophage, Antibiotic resistance, Salmonella, Bacteriophage-binding receptor, Gene expression

Posted Date: July 4th, 2019

DOl: https://doi.org/10.21203/rs.2.10995/v1

License: (c) (i) This work is licensed under a Creative Commons Attribution 4.0 International License. Read Full License 


\section{Abstract}

Background Bacteriophages have received great attention as alternative over antibiotics due to the host specificity. Therefore, this study was designed to evaluate the associations between bacteriophageinsensitive $(\mathrm{BI})$ and antibiotic-resistant mutants of Salmonella Typhimurium strains. Bacteriophagesensitive Salmonella Typhimurium ATCC 19585 (BSSTWT), ciprofloxacin-induced S. Typhimurium ATCC 19585 (BSSTCIP), S. Typhimurium KCCM 40253 (BSSTLAB), and clinically isolated multidrug-resistant S. Typhimurium CCARM 8009 (BSSTMDR) were used to induce the bacteriophage-insensitive mutants (BISTWT, BISTCIP, BISTLAB, and BISTMDR) against bacteriophage P22. Results The numbers of BSSTWT, BSSTCIP, and BSSTLAB were reduced by P22 (>3 log), while the least lytic activity was observed for BSSTMDR. BSSTWT treated with P22 showed the large variation in the cell state $(\mathrm{CV}>40 \%)$ and highest mutant frequency (62\%), followed by $25 \%$ for STCIP. The least similarities between BSSTWT and BISTWT were observed at P22 and PBST-13 $(<12 \%)$. The antibiotic susceptibilities were not significantly changed or slightly increased against BISTWT, BISTCIP, BISTLAB, and BISTMDR. The relative expression levels of bacteriophage-binding receptor-related genes (btuB, fhuA, fliK, fljB, ompC, ompF, rfaL, and tolC) were decreased in BISTCIP and BSSTMDR. Conclusion The results could pave the way for the application of bacteriophages as an alternative to control antibiotic-resistant bacteria.

\section{Background}

Over the last few decades, the emergence of antibiotic-resistant pathogens has become a serious threat to public health due to the risk of antibiotic treatment failure [1]. The misuse and overuse of antibiotics have accelerated the development of multidrug-resistant (MDR) pathogens [2]. MDR Salmonella strains are resistant to ampicillin, ceftriaxone, chloramphenicol, ciprofloxacin, gentamicin, kanamycin, nalidixic acid, streptomycin, sulfamethoxazole, and tetracycline, leading to high morbidity and mortality rates [2-5]. MDR Salmonella strains are one of the most common causes of infectious diseases with 90 million cases of gastroenteritis and approximately 155,000 deaths worldwide each year [1]. The current chemotherapeutic treatments become further complicated with MDR Salmonella infections. Therefore, the development of effective alternatives over antibiotics has been a major endeavor towards treatment of MDR Salmonella infections.

Recently, bacteriophages have received growing attention due to their host specificity $[6,7]$. The hostbacteriophage interaction depends on the ability of bacteriophages to bind the host cell receptors, including appendages, glycocalyx, and cell wall components $[8,9]$. However, there still remains a challenging question with respect to bacteriophage resistance. The alterations in the host cell receptors may confer the resistance to bacteriophages [10]. The bacterial host can evolve several bacteriophage resistance mechanisms, including inhibition of bacteriophage adsorption, prevention of bacteriophage DNA entry (superinfection exclusion system), degradation of bacteriophage DNA (restriction-modification system), development of abortive infection system, and CRISPR/Cas system [11-14]. The antibiotic resistance can result in the conformational change in bacteriophage-binding receptors on the host cell surface $[10,15]$. However, there is relatively few information on the relationship between bacteriophage 
resistance and antibiotic resistance in Salmonella Typhimurium. Therefore, this purpose of this study was to characterize the bacteriophage mutants of Salmonella Typhimurium in association with bacteriophage adsorption, antibiotic susceptibility, and gene expression.

\section{Methods}

\section{Bacterial Strains and Culture Conditions}

Strains of Salmonella Typhimurium ATCC 19585, S. Typhimurium KCCM 40253, and S. Typhimurium CCARM 8009 were obtained from American Type Culture Collection (ATCC; Manassas, VA, USA), Korean Culture Center of Microorganism (KCCM; Seoul, Korea), and Culture Collection of Antibiotic Resistant Microbes (CCARM; Seoul, Korea), respectively. The bacterial cells were cultured in trypticase soy broth (TSB; BD, Becton, Dickinson and Co., Sparks, MD, USA) at $37^{\circ} \mathrm{C}$ for $20 \mathrm{~h}$, centrifuged at $7000 \times g$ for 10 min at $4^{\circ} \mathrm{C}$, and washed with phosphate-buffered saline (PBS; pH 7.2). The harvested cells were diluted to $10^{8} \mathrm{CFU} / \mathrm{mL}$ for further assays.

\section{In vitro Stepwise Selection Assay}

To induce antibiotic-resistant S. Typhimurium ATCC 19585 was exposed with serially increasing ciprofloxacin concentrations according to the serial passage procedure [16]. Salmonella Typhimurium ATCC 19585 was repeatedly cultured in TSB and trypticase soy agar (TSA) containing ciprofloxacin concentrations from 0.0078 to $1 \mu \mathrm{g} / \mathrm{mL}$. The ciprofloxacin-induced resistant $S$. Typhimurium ATCC 19585 was stable for more than ten passages in antibiotic-free TSB at $37^{\circ} \mathrm{C}$ for $20 \mathrm{~h}$ prior to use.

\section{Bacteriophage Propagation}

Salmonella bacteriophages, P22, P22-B1, PBST-10, PBST-13, PBST-32, and PBST-35, were obtained from ATCC and Bacteriophage Bank at Hankuk University of Foreign Studies (Yongin, Gyeonggi, Korea). All bacteriophages were propagated at $37^{\circ} \mathrm{C}$ for $20 \mathrm{~h}$ in TSB containing S. Typhimurium KCCM 40253. The propagated bacteriophages were collected by centrifuging at $6000 \times \mathrm{g}$ for $10 \mathrm{~min}$, filtered through by a $0.2-\mu \mathrm{m}$ filter to remove bacterial lysates, and further purified using polyethylene glycol (PEG) precipitation assay [17]. The titers of bacteriophage were determined by using a soft-agar overlay method [18]. In brief, the selected bacteriophages were serially (1:10) diluted with PBS and gently mixed with the host cells $\left(10^{7} \mathrm{CFU} / \mathrm{mL}\right)$ in TSB containing $0.5 \%$ agar. The mixture was poured onto the pre-warmed base agar and solidified at room temperature, and then incubated at $37^{\circ} \mathrm{C}$ for $20 \mathrm{~h}$ to enumerate the bacteriophages expressed as a plaque-forming unit (PFU). 


\section{Lytic Activity of Bacteriophage}

Salmonella bacteriophages (P22, P22-B1, PBST-10, PBST-13, PBST-32, and PBST-35) were used to evaluate the lytic activity against $S T^{W T}, S T^{C I P}, S T^{\mathrm{LAB}}$, and $S T^{\mathrm{MDR}}$. The selected strains $\left(10^{8} \mathrm{CFU} / \mathrm{mL}\right.$ each $)$ were mixed with bacteriophage $\left(10^{10} \mathrm{PFU} / \mathrm{mL}\right.$ each) and incubated at $37^{\circ} \mathrm{C}$ for $10 \mathrm{~min}$. The incubated cultures were centrifuged at $6,000 \times \mathrm{g}$ for 5 min, serially diluted (1:10) with PBS, and plated on TSA using an Autoplate ${ }^{\circledR}$ Spiral Plating System (Spiral Biotech Inc.). The plates were incubated at $37^{\circ} \mathrm{C}$ for $24-48 \mathrm{~h}$. The lytic activity was expressed as $\log \mathrm{N} / \mathrm{N}_{0} ; \mathrm{N}$ and $\mathrm{N}_{0}$ denote the counts of bacterial cells treated with and without bacteriophages, respectively.

\section{Fluctuation Assay}

The fluctuation assay was used to determine mutant distribution whether $S T^{\mathrm{WT}}, \mathrm{ST} \mathrm{T}^{\mathrm{CIP}}, \mathrm{ST} \mathrm{T}^{\mathrm{LAB}}$, and $\mathrm{ST} T^{\mathrm{MDR}}$ mutants were spontaneous or inducible in the presence of bacteriophages [19]. In brief, ST ${ }^{W T}, S T^{C I P}$, $\mathrm{ST}^{\mathrm{LAB}}$, or ST ${ }^{\mathrm{MDR}}$ cells $\left(10^{3} \mathrm{CFU} / \mathrm{mL}\right)$ were distributed into 10 test tubes $(0.2 \mathrm{~mL}$; Group $\mathrm{A})$ and one test tube ( $2 \mathrm{~mL}$; Group B). The tubes were incubated at $37^{\circ} \mathrm{C}$ for $3 \mathrm{~h}$. Group A (1 replicate/tube) and Group B (10 replicates/tube) were plated on TSA with P22 and incubated for $37^{\circ} \mathrm{C}$ for $24-48 \mathrm{~h}$ to enumerate viable cells.

\section{Induction of Bacteriophage-insensitive Salmonella Typhimurium}

Bacteriophage P22-insensitive mutant $S$. Typhimurium ATCC 19585 (STWT), ciprofloxacin-induced $S$. Typhimurium ATCC 19585 (ST ${ }^{\text {CIP }}$ ), S. Typhimurium KCCM 40253 (ST ${ }^{\text {LAB }}$ ), and clinically isolated multidrug-resistant $S$. Typhimurium CCARM 8009 (STMDR) were isolated using the spot plate assay [20]. P22 $\left(2 \times 10^{6} \mathrm{PFU} / 5 \mu \mathrm{l}\right)$ were spotted on $0.5 \%$ soft-agar containing BSST ${ }^{\mathrm{WT}}$, BSST ${ }^{\mathrm{CIP}}, \mathrm{BSST}^{\mathrm{LAB}}$, and $\mathrm{BSST}^{\mathrm{MDR}}\left(10^{7} \mathrm{CFU} / \mathrm{mL}\right.$ each) and incubated at $37^{\circ} \mathrm{C}$ until recovery of host cells within the clear zone, which were assigned as BIST ${ }^{\mathrm{WT}}$, BIST ${ }^{\mathrm{CIP}}, \mathrm{BIST}^{\mathrm{LAB}}$, and BIST ${ }^{\mathrm{MDR}}$, respectively. The isolated colonies were subcultured in TSB at $37^{\circ} \mathrm{C}$ for $20 \mathrm{~h}$. The BIST cells were suspended gently in $0.5 \%$ soft-agar plates and poured onto the pre-warmed base agar. The 10 -fold diluted P22 ( $5 \mu \mathrm{l} \mathrm{each})$ was spotted onto the plates. After $20 \mathrm{~h}$ incubation at $37^{\circ} \mathrm{C}$, the bacteriophage-insensitive mutants (BIST ${ }^{\mathrm{WT}}, \mathrm{BIST}^{\mathrm{CIP}}, \mathrm{BIST}^{\mathrm{LAB}}$, and $\mathrm{BIST}^{\mathrm{MDR}}$ ) were tested for the multiple-resistance to P22, P22-B1, PBST-10, PBST-13, PBST-32, and PBST35 .

\section{Mutant Frequency Assay}


The mutation rates of $S T^{\mathrm{WT}}, S T^{\mathrm{CIP}}, \mathrm{ST}^{\mathrm{LAB}}$, and $\mathrm{ST} \mathrm{T}^{\mathrm{MDR}}$ cultured in the absence and presence of $\mathrm{P} 22$ for 48 $\mathrm{h}$ were estimated on the TSA containing bacteriophages $\left(10^{7} \mathrm{PFU} / \mathrm{mL}\right)$. The cultured cells were plated on TSA with and without bacteriophages and incubated at $37^{\circ} \mathrm{C}$ for $24-48 \mathrm{~h}$. The mutant frequencies were estimated as the proportion of the numbers of surviving colonies on the TSA with and without bacteriophages.

\section{Lysogenic Induction Assay}

Lysogenic cells were induced by mitomycin $C$ [18]. In brief, the cultured BSST ${ }^{W T}, B^{2} S^{C I P}, B S S T^{L A B}$, $\mathrm{BSST}^{\mathrm{MDR}}$, BIST ${ }^{\mathrm{WT}}, \mathrm{BIST}^{\mathrm{CIP}}, \mathrm{BIST}{ }^{\mathrm{LAB}}$, and BIST ${ }^{\mathrm{MDR}}$ were treated with mitomycin $\mathrm{C}(0.5 \mu \mathrm{g} / \mathrm{mL})$ at $37^{\circ} \mathrm{C}$ for $2 \mathrm{~h}$. After incubation, the mixtures were centrifuged at $7000 \times g$ for $5 \mathrm{~min}$ and filtered through a $0.2-\mu \mathrm{m}$ filter. The collected supernatants were spot tested to confirm the lytic bacteriophages against BSST ${ }^{\mathrm{LAB}}$.

\section{Bacteriophage Adsorption Assay}

Bacteriophage adsorption rates were estimated to evaluate the bacteriophage-binding receptors on the bacteriophage-sensitive and bacteriophage-insensitive $S T^{W T}, S^{C I P}, S T^{L A B}$, and STMDR. In brief, BSSTWT, $\mathrm{BSST}^{\mathrm{CIP}}, \mathrm{BSST}^{\mathrm{LAB}}, \mathrm{BSST}^{\mathrm{MDR}}, \mathrm{BIST} \mathrm{WT}^{\mathrm{WT}}, \mathrm{BIST} \mathrm{CIP}^{\mathrm{C}}, \mathrm{BIST} \mathrm{T}^{\mathrm{LAB}}$, and BIST ${ }^{\mathrm{MDR}}\left(10^{6} \mathrm{CFU} / \mathrm{mL}\right)$ were infected with the bacteriophages (P22, P22-B1, PBST-10, PBST-13, PBST-32, and PBST-35) at MOI of 0.1 and then allowed to adsorb at $37^{\circ} \mathrm{C}$ for $15 \mathrm{~min}$. After incubation, the cultures were centrifuged at $16,000 \times \mathrm{g}$ for $2 \mathrm{~min}$ at $4^{\circ} \mathrm{C}$. The supernatants were serially diluted and plated to determine unabsorbed bacteriophage titers according to a soft-agar overlay assay. The adsorption percentage was estimated using the equation: Adsorption rate $(\%)=[($ initial phage titer-phage titer in the supernatant) $/($ initial phage titer $)] \times 100$.

\section{Antibiotic Susceptibility Assay}

The antibiotic susceptibilities of BSST ${ }^{\mathrm{WT}}, \mathrm{BSST}^{\mathrm{CIP}}, \mathrm{BSST}^{\mathrm{LAB}}$, and $\mathrm{BSST}^{\mathrm{MDR}}$ were determined by using an agar disc diffusion assay to compare with those of BIST ${ }^{\mathrm{WT}}, \mathrm{BIST}^{\mathrm{CIP}}, \mathrm{BIST}^{\mathrm{LAB}}$, and BIST ${ }^{\mathrm{MDR}}$. The cultured cells (0.5 McFarlan) were spread on Mueller-Hinton agar plate and then allowed to dry for $5 \mathrm{~min}$. The antibiotic discs (Becton, Dickinson and Company, NJ, USA), including ampicillin (10 $\mu \mathrm{g})$, cephalothin (30 $\mu \mathrm{g})$, chloramphenicol $(30 \mu \mathrm{g})$, ciprofloxacin $(5 \mu \mathrm{g})$, erythromycin $(15 \mu \mathrm{g})$, imipenem $(10 \mu \mathrm{g})$, streptomycin $(10 \mu \mathrm{g})$, and tetracycline $(30 \mu \mathrm{g})$ were placed on the surface on Mueller-Hinton agar and incubated at $37^{\circ} \mathrm{C}$ for $20 \mathrm{~h}$. The diameter of the inhibition zone was measured by using a digital vernier caliper to evaluate the antibiotic susceptibility. 


\section{Quantitative RT-PCR Assay}

Total RNA was extracted from BSST ${ }^{\mathrm{WT}}$, $\mathrm{BSST}^{\mathrm{CIP}}, \mathrm{BSST}^{\mathrm{LAB}}, \mathrm{BSST}^{\mathrm{MDR}}, \mathrm{BIST}^{\mathrm{WT}}, \mathrm{BIST}^{\mathrm{CIP}}, \mathrm{BIST}^{\mathrm{LAB}}$, and BIST $^{\mathrm{MDR}}$ according to the protocol of RNeasy Protect Bacteria Mini kit protocol (Qiagen, Hilden, Germany). The pre-cultured cells were mixed with $1 \mathrm{~mL}$ of RNA protect Bacteria Reagent to stabilize RNA, and the mixture were centrifuged at $5,000 \times \mathrm{g}$ for $10 \mathrm{~min}$. The collected cells were lysed with a lysozymecontaining buffer TE (10 mM Tris· $\mathrm{Cl}, 1 \mathrm{mM}$ EDTA, pH 8.0). The lysate cells were mixed with $95 \%$ ethanol to extract RNA through an RNeasy mini column. According to the QuantiTech reverse transcription procedure (Qiagen), cDNA was synthesized. Briefly, the RNA extracts were rinsed with a Wipe buffer to remove genomic DNA and mixed with a master mixture containing reverse transcriptase, RT buffer, and RT primer mix. The mixture was incubated at $42^{\circ} \mathrm{C}$ for $15 \mathrm{~min}$ followed by $95^{\circ} \mathrm{C}$ for $3 \mathrm{~min}$. For amplification, the PCR mixture $(20 \mu \mathrm{l})$ containing $10 \mu \mathrm{l}$ of $2 \times$ QuantiTect SYBR Green PCR Master, $2 \mu \mathrm{l}$ of each primer, and $2 \mu \mathrm{l}$ of $\mathrm{CDNA}$, and $4 \mu \mathrm{l}$ of RNase-free water was denatured at $95^{\circ} \mathrm{C}$ for $30 \mathrm{sec}$, followed by 45 cycles of $95^{\circ} \mathrm{C}$ for $5 \mathrm{sec}, 55^{\circ} \mathrm{C}$ for $20 \mathrm{sec}$, and $72^{\circ} \mathrm{C}$ for $15 \mathrm{sec}$ using an QuantStudio ${ }^{\mathrm{TM}} 3$ Real-Time PCR System (Applied Biosystems ${ }^{\mathrm{TM}}$, USA). The synthesized oligonucleotide primers used in this study are listed in Table 1. The relative gene expression levels were determined using the comparative method [21].

\section{Statistical Analysis}

All analyses were performed in duplicate on three replicates. Data were analyzed using Statistical Analysis System (SAS). The general linear model (GLM) and least significant difference (LSD) procedures were used to determine significant mean differences among treatments at $P<0.05$.

\section{Results}

\section{Lytic activity of Bacteriophages against Salmonella Typhimurium}

The lytic activities of bacteriophages (P22, P22-B1, PBST-10, PBST-13, PBST-32, and PBST-35) against Salmonella Typhimurium ATCC $19585\left(\right.$ ST $\left.^{\mathrm{WT}}\right)$, ciprofloxacin-induced S. Typhimurium ATCC 19585 (STCIP), S. Typhimurium KCCM 40253 (ST ${ }^{\mathrm{LAB}}$ ), and clinically isolated multidrug-resistant $S$. Typhimurium CCARM 8009 (STMDR) were determined as shown in Figure 1. The highest lytic activities of P22 were observed against $S T^{W T}, S T^{C I P}$, and $S T^{\mathrm{LAB}}$, showing more than 3 log reduction. Most bacteriophages had the least lytic activities against $\mathrm{ST}^{\mathrm{MDR}}(<1$ log reduction).

\section{Variability in Inherited and Induced Mutation in Salmonella Typhimurium}

Fluctuation assay was used to evaluate the cell states of $S T^{W T}, S T^{C I P}, S T^{L A B}$, and $S T^{M D R}$, which can determine whether mutants were inherited (spontaneous) or induced in the presence of bacteriophages 
[19]. $S T^{W T}, S T^{\mathrm{LAB}}$, and $\mathrm{ST} T^{\mathrm{MDR}}$ showed large variation in group $\mathrm{A}(\mathrm{CV}>40 \%)$ and small variation $(\mathrm{CV}<$ $12 \%$ ) from group $B$, while the small variations were observed in $S T^{C I P}$ from both group $A$ and group $B$ (Figure S1). The bacteriophage-induced mutation in $S T^{W T}, S T^{C I P}, S T^{L A B}$, and $S T^{M D R}$ was determined to evaluate the mutant frequency in the presence of bacteriophages (Figure S2). STWT, STCIP, ST ${ }^{\mathrm{LAB}}$, and $S T^{M D R}$ varied in the resistance to bacteriophage. $S T^{\mathrm{WT}}$ treated with $\mathrm{P} 22$ had the highest mutant frequency of $62 \%$, followed by $25 \%$ for $S T^{\mathrm{CIP}}$.

\section{Lytic Activity and Bacteriophage Specificity for P22-mutant Salmonella Typhimurium}

The P22-induced BIST ${ }^{\mathrm{WT}}$, BIST ${ }^{\mathrm{LAB}}$, and BIST ${ }^{\mathrm{MDR}}$ exhibited the resistance to $\mathrm{P} 22$ and $\mathrm{P} 22-\mathrm{B} 1$, while those were still susceptible to other bacteriophages (PBST-10, PBST-13, PBST-32, and PBST-35) (Figure S3). BIST ${ }^{\mathrm{CIP}}$ was resistant to P22, P22-B1, PBST-32, and PBST-35. A dendrogram was depicted based on the adsorption rates of bacteriophages (P22, P22-B1, PBST-10, PBST-13, PBST-32, and PBST-35) to bacteriophage-sensitive (BS) and bacteriophage-insensitive (BI) $\mathrm{ST}^{\mathrm{WT}}, \mathrm{ST}^{\mathrm{CIP}}, \mathrm{ST}^{\mathrm{LAB}}$, and $\mathrm{ST}{ }^{\mathrm{MDR}}$. The highest similarities between BSST ${ }^{\mathrm{WT}}$ and BIST ${ }^{\mathrm{WT}}$ were observed at PBST-35 (85\%), followed by PBST-10 (78\%), P22-B1 (76\%), and PBST-32 (63\%), while the least similarities were observed at P22 and PBST-13 (<12\%) (Figure 2). The similarities between BSST ${ }^{\mathrm{CIP}}$ and BIST ${ }^{\mathrm{CIP}}$ were $68 \%$ at PBST-10 and $86 \%$ at PBST13. BSST ${ }^{\mathrm{CIP}}$ and BIST ${ }^{\mathrm{CIP}}$ at P22, P22-B1, PBST-32, and PBST-35 had similarities of less than $20 \%$. The highest similarity between $B S S T^{\mathrm{LAB}}$ and $B I S T^{\mathrm{LAB}}$ was $95 \%$ at $\mathrm{PBST}-13$, while the least similarities were observed at P22, PBST-32, and PBST-35. BSST ${ }^{\mathrm{MDR}}$ and BIST ${ }^{\mathrm{MDR}}$ at PBST-13, and PBST-35 had similarities of $99 \%$ and $95 \%$, respectively. No similarities were observed between BSST ${ }^{M D R}$ and BIST ${ }^{M D R}$ at PBST-10 and PBST-32.

\section{Lysogenic Conversion of Bacteriophage-insensitive Salmonella Typhimurium Mutants}

The lysogen induction assay were performed to evaluate whether the bacteriophage resistance was owing to BIST ${ }^{W T}$, BIST ${ }^{\mathrm{CIP}}, \mathrm{BIST} \mathrm{T}^{\mathrm{LAB}}$, and BIST ${ }^{\mathrm{MDR}}$ lysogenic cells (Figure S4). BIST ${ }^{\mathrm{WT}}$ and BIST ${ }^{\mathrm{LAB}}$ treated with mitomycin $C$ exhibited lytic growth, indicating that the P22-resistant BIST ${ }^{W T}$ and BIST ${ }^{L A B}$ strains have inducible prophages. However, BIST ${ }^{C I P}$ and BIST ${ }^{M D R}$ treated with mitomycin $\mathrm{C}$ did not show phage plaque, suggesting that the $\mathrm{P} 22$ was not lysogenized in the BIST ${ }^{\mathrm{CIP}}$ and BIST ${ }^{\mathrm{MDR}}$ (Figure S4).

\section{Antibiotic Susceptibility of Bacteriophage-insensitive Salmonella Typhimurium Mutants}

The antibiotic susceptibilities of $B S S T^{\mathrm{WT}}, \mathrm{BSST}^{\mathrm{CIP}}, \mathrm{BSST}^{\mathrm{LAB}}$, and $\mathrm{BSST}^{\mathrm{MDR}}$ were evaluated using disk diffusion assay and compared with those of BIST ${ }^{W T}, B I S T^{C I P}, B I S T^{L A B}$, and BSST ${ }^{M D R}$, respectively (Figure 
3). No noticeable changes in antibiotic susceptibilities were observed between bacteriophage-sensitive and bacteriophage-insensitive strains (Figure $3 \mathrm{~A}$ ). The susceptibilities of BIST ${ }^{\mathrm{CIP}}, \mathrm{BIST}^{\mathrm{LAB}}$, and BIST ${ }^{\mathrm{MDR}}$ were significantly increased to ciprofloxacin (Figure 3B), ampicillin (Figure 3C), and tetracycline (Figure 3D), respectively, compared to $B S S T^{C I P}, B S S T^{L A B}$, and BSST ${ }^{M D R}$.

\section{Gene Expression in Bacteriophage-insensitive Salmonella Typhimurium Mutants}

The relative gene expression of btuB, fhuA, flik, fljB, ompC, ompF, rfaL, seiA, stn, and tolC were observed in BIST ${ }^{\mathrm{WT}}$, BIST ${ }^{\mathrm{CIP}}$, BIST ${ }^{\mathrm{LAB}}$, and BIST ${ }^{\mathrm{MDR}}$ compared to BSST ${ }^{\mathrm{WT}}, \mathrm{BSST}^{\mathrm{CIP}}, \mathrm{BSST}^{\mathrm{LAB}}$, and $\mathrm{BSST}^{\mathrm{MDR}}$ (Figure 4). Most genes were slightly overexpressed in BIST ${ }^{\mathrm{WT}}$ and $\mathrm{BIST} \mathrm{T}^{\mathrm{LAB}}$, while the relative expression levels of most genes were significantly decreased in BIST ${ }^{\mathrm{CIP}}$ and BIST ${ }^{\mathrm{MDR}}$. The $\operatorname{sie} A$ was highly overexpressed in BIST ${ }^{W T}$ by 11 -fold and BIST ${ }^{\mathrm{LAB}}$ by 18 -fold, while the relative expression levels of stn was decreased in the BIST ${ }^{\mathrm{CIP}}$ by 7 -fold and BIST ${ }^{\mathrm{MDR}}$ by 4 -fold.

\section{Discussion}

The application of bacteriophages for combatting antibiotic-resistant bacteria is often impeded by bacteriophage resistance [22]. However, bacteria under selection pressure can lead to a trade-off between bacteriophage-resistance and antibiotic resistance [23]. Therefore, this study describes the association between bacteriophage-resistance and antibiotic resistance in $S$. Typhimurium with different levels of antibiotic resistance, which needs to design effective bacteriophage-based therapy to control antibioticresistant bacteria.

$\mathrm{P} 22$ was able to most effectively lyse $S T^{\mathrm{WT}}, \mathrm{ST}^{\mathrm{CIP}}$, and $\mathrm{ST}^{\mathrm{LAB}}$ (Figure 1). The efficacy of lytic activity of bacteriophages depend on the specific recognition between bacterial cell surface receptors and receptorbinding proteins of bacteriophages [8]. As shown in Figure 2, the large variation from group A and small variation from group $B$ imply that mutation was induced before bacteriophage infection [19]. The mutation occurred spontaneously before exposure to selection pressure. The alteration in bacteriophagebinding receptors on the host cells can lead bacteriophage-insensitive mutants [24]. The resistance of $B I S T^{L A B}$ to $P 22$ was also due to the lysogenic conversion, which can lead superinfection exclusion [25]. This was confirmed by the lysogenic induction assay, showing that prophages were induced from the $\mathrm{BIST}^{\mathrm{WT}}$ and BIST ${ }^{\mathrm{LAB}}$ after mitomycin $\mathrm{C}$ treatment (Figure S4).

Numerous Salmonella-specific bacteriophages that use LPS as a receptor can modify LPS to protect from superinfection when host cells are lysogenied $[26,27]$. Recently, two copies of lipopolysaccharide modification acyltransferase and GtrA are found on the genome of lysogenic P22-like bacteriophage [28]. Although the modification of LPS protects the lysogeny from superinfection by LPS targeting bacteriophage, the lysogeny is still susceptible to bacteriophages that target other receptors such as 
flagella [28] (Figure S3). The multiple resistance of BIST ${ }^{\mathrm{CIP}}$ might be attributed to the mutation in genes encoding bacteriophage-binding receptors [24]. The loss of bacteriophage-binding receptors is directly associated with the decrease in lytic ability of bacteriophages [8].

The highest similarity indicates that bacteriophage-binding receptors were not altered at the mutants. However, the least similarity suggests that bacteriophage-binding receptors were changed after bacteriophage-induced mutation. P22-B1 (76\%), PBST-10 (78\%), and PBST-35 (85\%) might share common receptors on the BSST ${ }^{\mathrm{WT}}$ and $\mathrm{BIST}{ }^{\mathrm{WT}}$. PBST-10 (68\%) and PBST-13 (86\%) might share common receptors on the $\mathrm{BSST}^{\mathrm{CIP}}$ and $\mathrm{BIST}{ }^{\mathrm{CIP}}, \mathrm{P} 22-\mathrm{B} 1$ (77\%) and PBST-13 $(95 \%)$ on the $\mathrm{BSST}^{\mathrm{CIP}}$ and $\mathrm{BIST}^{\mathrm{CIP}}$, and PBST-13 (99\%) and PBST-35 (95\%) on the BSST ${ }^{\mathrm{MDR}}$ and BIST ${ }^{\mathrm{MDR}}$. The adsorption similarities between BS and $\mathrm{BI}$ S. Typhimurium strains were well corresponded to the lytic activities with the exception of BSSTWT and BIST ${ }^{\mathrm{WT}}$ against P22-B1, BSST ${ }^{\mathrm{WT}}$ and BIST ${ }^{\mathrm{WT}}$ against PBST-13, BSST ${ }^{\mathrm{LAB}}$ and BIST ${ }^{\mathrm{LAB}}$ against P22-1, and $\mathrm{BSST}^{\mathrm{CIP}}$ and BIST ${ }^{\mathrm{CIP}}$ against PBST-12 (Figure S3). The results might be due to the alteration of bacteriophage-binding receptors, resulting in the change in binding affinity. The bacteriophageinsensitivity and antibiotic resistance contributed to the alteration of bacteriophage-binding receptors on the host cells, which may ultimately result in the decrease in bacteriophage adsorption rate and lytic activity [29]. However, a high adsorption rate does not always linked to a lytic activity [30]. The bacteriophage adsorption rate to the host cells having various receptors are not much affected by their alteration [31]. The antibiotic susceptibility patterns of bacteriophage-insensitive mutants are more likely to increase in the BIST ${ }^{\mathrm{CIP}}$, BIST ${ }^{\mathrm{LAB}}$, and BIST ${ }^{\mathrm{MDR}}$ (Figure 3). The bacteriophage resistant mutants produce an evolutionary trade-off in antibiotic-resistant bacteria, which can change the phage binding receptors and efflux pump system, resulting in increased susceptibility to several classes of antibiotic [23].

The decrease in relative expression of btuB, fhuA, fliK, fljB, ompC, ompF, rfaL, and tolC was well corresponded to the low adsorption rates of bacteriophages to $\mathrm{BIST}^{\mathrm{CIP}}$ and $\mathrm{BSST} \mathrm{MDR}^{\mathrm{M}}$ (Figure 4). Bacteriophage tail proteins bind to the host surface proteins, polysaccharides, and lipopolysaccharides, responsible for host specificity and range [32]. BtuB (vitamin B12 transporter), FhuA (Ferrichrome outer membrane transporter), FliK (flagella hook), OmpC (outer membrane protein), OmpF (outer membrane protein), RfaL (O-antigen ligase), and TolC (innate efflux pump) can serve as surface receptors for bacteriophages $[28,29,32]$. The $\mathrm{OmpC}, \mathrm{OmpF}$, and TolC contribute to multidrug-resistance in bacteria. This confirms the antibiotic susceptibilities were increased against BIST ${ }^{C I P}, B^{B S T}{ }^{\mathrm{LAB}}$, and BIST ${ }^{\mathrm{MDR}}$ when compared to the BSST ${ }^{\mathrm{CIP}}, \mathrm{BSST}^{\mathrm{LAB}}$, and BSST ${ }^{\mathrm{MDR}}$ (Figure 3). Bacteria can adapt to the selective pressure imposed by bacteriophages, leading to antibiotic resistance. This suggests that the bacterial resistance to bacteriophages is related to the antibiotic resistance [33]. The overexpression of $\operatorname{sieA}$ in BIST ${ }^{\mathrm{WT}}$ and $B I S T^{\mathrm{LAB}}$ (Figure 4) implies that these mutants might be due to the lysogenic conversion, preventing the entry of superinfecting bacteriophage DNA into the host [34]. The product of $\operatorname{sie} A$ is an inner membrane protein of P22-lysogenic Salmonella Typhimurium [14]. The suppression of stn in the BISTCIP and $B I S T^{M D R}$ is in a good agreement with the previous observations that the bacteriophages-insensitive mutants exhibited the reduced virulence in antibiotic-resistant bacteria [35]. 


\section{Conclusions}

The most significant findings in this study were that (i) P22-induced BIST ${ }^{\mathrm{CIP}}$ mutant had multiple resistance to P22, P22-B1, PBST-32, and PBST-35, (ii) the superinfection exclusion occurred at P22induced $B I S T^{W T}$ and $B I S T^{L A B}$, (iii) the adsorption rates were varied between $B S$ and $B I S$. Typhimurium strains, (iv) antibiotic susceptibilities were increased in the BIST ${ }^{C I P}, B I S T^{L A B}$, and BIST ${ }^{M D R}$, and (v) the virulence was reduced in the BIST ${ }^{\mathrm{CIP}}$ and $B I S T^{\mathrm{MDR}}$. The results pointed out that the bacteriophage-binding receptors were altered in the $\mathrm{BI}$ mutant $S$. Typhimurium strains, which did not induce cross-resistance to antibiotics. The results provide useful information for designing effective treatments in bacteriophage alone or combination of bacteriophages and antibiotics that reduce the risk of antibiotic resistance in bacteria. However, further study is needed to understand the association between bacteriophage insensitivity and antibiotic resistance.

\section{Declarations}

\section{Acknowledgements}

Not applicable.

\section{Funding}

This research was supported by Basic Science Research Program through the National Research Foundation of Korea (NRF) funded by the Ministry of Education (NRF-2016R1D1A3B01008304).

\section{Availability of data and materials}

The data supporting the conclusions are included within the manuscript and also provided in additional files.

\section{Author's contributions}

MJU conducted all experiments and also contributed to the writing and preparation of the manuscript. JA contributed to the experimental design, data interpretation, and manuscript writing. All authors read and approved the final manuscript.

\section{Competing interests}

The authors declare that they have no competing interests.

\section{Consent for publication}

Not applicable.

\section{Ethics approval and consent to participate}


Not applicable.

\section{Open Access}

This article is distributed under the terms of the Creative Commons Attribution 4.0 International License (http://creativecommons.org/licenses/by/4.0/), which permits unrestricted use, distribution, and reproduction in any medium, provided you give appropriate credit to the original author(s) and the source, provide a link to the Creative Commons license, and indicate if changes were made. The Creative Commons Public Domain Dedication waiver (http://creativecommons.org/publicdomain/zero/1.0/) applies to the data made available in this article, unless otherwise stated.

\section{References}

1. Eng S-K, Pusparajah P, Ab Mutalib N-S, Ser H-L, Chan K-G, Lee L-H. Salmonella: A review on pathogenesis, epidemiology and antibiotic resistance. Front Life Sci. 2015;8(3):284-93.

2. Parisi A, Crump JA, Kirk M, Glass K, Howden B, Gray D et al. Health outcomes from multi-drugresistant Salmonella infections in high-income countries: A systematic review and meta-analysis. Open Forum Infect Dis. 2017;4(Suppl 1):S286-S.

3. Mulvey MR, Finley R, Allen V, Ang L, Bekal S, El Bailey S et al. Emergence of multidrug-resistant Salmonella enterica serotype involving human cases in Canada: results from the Canadian Integrated Program on Antimicrobial Resistance Surveillance (CIPARS), . The Journal of antimicrobial chemotherapy. 2013;68(9):1982-6.

4. Folster JP, Campbell D, Grass J, Brown AC, Bicknese A, Tolar B et al. Identification and characterization of multidrug-resistant Salmonella enterica serotype Albert isolates in the United States. Antimicrob Agent Chemother. 2015;59(5):2774-9.

5. Klemm EJ, Shakoor S, Page AJ, Qamar FN, Judge K, Saeed DK et al. Emergence of an extensively drug-resistant Salmonella enterica serovar typhi clone harboring a promiscuous plasmid encoding resistance to fluoroquinolones and third-generation cephalosporins. mBio. 2018;9(1):e00105-18.

6. Schroeder M, Brooks BD, Brooks AE. The complex relationship between virulence and antibiotic resistance. Genes. 2017;8(1):39.

7. Knodler LA, Vallance BA, Hensel M, Jäckel D, Finlay BB, Steele-Mortimer O. Salmonella type III effectors PipB and PipB2 are targeted to detergent-resistant microdomains on internal host cell membranes. Mol Microbiol. 2003;49(3):685-704.

8. Rakhuba DV, Kolomiets El, Dey ES, Novik GI. Bacteriophage receptors, mechanisms of phage adsorption and penetration into host cell. Polish J Microbiol. 2010;59(3):145-55.

9. Le S, He X, Tan Y, Huang G, Zhang L, Lux R et al. Mapping the tail fiber as the receptor binding protein responsible for differential host specificity of Pseudomonas aeruginosa bacteriophages PaP1 and JG004. PLoS ONE. 2013;8(7):e68562. 
10. Qimron U, Marintcheva B, Tabor S, Richardson CC. Genomewide screens for Escherichia coli genes affecting growth of T7 bacteriophage. Proc Nat Acad Sci. 2006;103(50):19039-44.

11. Nikaido H, Rosenberg EY, Foulds J. Porin channels in Escherichia coli: studies with beta-lactams in intact cells. J Bacteriol. 1983;153(1):232-40.

12. Michael GB, Schwarz S. Antimicrobial resistance in zoonotic nontyphoidal Salmonella; an alarming trend? Clin Microbiol Infect. 2016;22(12):968-74.

13. Örmälä A-M, Jalasvuori M. Phage therapy: Should bacterial resistance to phages be a concern, even in the long run? Bacteriophage. 2013;3(1):e24219.

14. Labrie SJ, Samson JE, Moineau S. Bacteriophage resistance mechanisms. Nat Rev Microbiol. 2010;8(5):317-27.

15. Hirai K, Aoyama H, Irikura T, lyobe S, Mitsuhashi S. Differences in susceptibility to quinolones of outer membrane mutants of Salmonella typhimurium and Escherichia coli. Antimicrob Agent Chemother. 1986;29(3):535-8.

16. Michéa-Hamzehpour M, Kahr A, Pechère JC. In vitro stepwise selection of resistance to quinolones, $\beta$ lactams and amikacin in nosocomial gram-negative bacilli. Infection. 1994;22(2):S105-S10.

17. Wong CL, Sieo CC, Tan WS, Abdullah N, Hair-Bejo M, Abu J et al. Evaluation of a lytic bacteriophage, $\Phi$ st1, for biocontrol of Salmonella enterica serovar Typhimurium in chickens. Int J Food Microbiol. 2014;172(2):92-101.

18. Bielke L, Higgins S, Donoghue A, Donoghue D, Hargis BM. Salmonella host range of bacteriophages that infect multiple genera. Poult Sci. 2007;86(12):2536-40.

19. Le S, Yao X, Lu S, Tan Y, Rao X, Li M et al. Chromosomal DNA deletion confers phage resistance to Pseudomonas aeruginosa. Sci Rep. 2014;4:1-8.

20. Reinheimer JA, Suarez VB, Ballo NB, Zalazar CA. Microbiological and technological characteristics of natural whey cultures for Argentinian hard-cheese production. J Food Prot. 1995;58:796-9.

21. Livak KJ, Schmittgen TD. Analysis of relative gene expression data using real-time quantitative PCR and the $2^{-\Delta \Delta C T}$ Method. Method. 2001;25(4):402-8.

22. Mizoguchi K, Morita M, Fischer CR, Yoichi M, Tanji Y, Unno H. Coevolution of Bacteriophage PP01 and Escherichia coli 0157:H7 in Continuous Culture. Appl Environ Microbiol. 2003;69(1):170-6.

23. Chan BK, Turner PE, Kim S, Mojibian HR, Elefteriades JA, Narayan D. Phage treatment of an aortic graft infected with Pseudomonas aeruginosa. Evolution, Medicine, and Public health. 2018;2018(1):60-6.

24. Koskella B, Brockhurst MA. Bacteria-phage coevolution as a driver of ecological and evolutionary processes in microbial communities. FEMS Microbiol Rev. 2014;38(5):916-31.

25. Brussow H, Canchaya C, Hardt W-D. Phages and the evolution of bacterial pathogens: from genomic rearrangements to lysogenic conversion. Microbiol Mol Biol Rev. 2004;68(3):560-602.

26. Kropinski AM, Kovalyova IV, Billington SJ, Patrick AN, Butts BD, Guichard JA et al. The genome of $\varepsilon 15$, a serotype-converting, Group E1 Salmonella enterica-specific bacteriophage. Virology. 
2007;369(2):234-44.

27. Villafane R, Zayas M, Gilcrease EB, Kropinski AM, Casjens SR. Genomic analysis of bacteriophage ع34 of Salmonella entericaserovar Anatum (15+). BMC Microbiol. 2008;8(1):227.

28. Shin H, Lee J-H, Kim H, Choi Y, Heu S, Ryu S. Receptor diversity and host interaction of bacteriophages infecting Salmonella enterica serovar Typhimurium. PLoS ONE. 2012;7(8):e43392.

29. Silva JB, Storms Z, Sauvageau D. Host receptors for bacteriophage adsorption. FEMS Microbiol Lett. 2016;363(4):fnw002-fnw.

30. Thanki AM, Taylor-Joyce G, Dowah A, Yakubu Nale J, Malik D, Rebecca Jane Clokie M. Unravelling the links between phage adsorption and successful infection in Clostridium difficile. Viruses. 2018;10(8):411.

31. Marston MF, Martiny JBH. Genomic diversification of marine cyanophages into stable ecotypes. Environ Microbiol. 2016;18(11):4240-53.

32. Chaturongakul S, Ounjai P. Phage-host interplay: examples from tailed phages and Gram-negative bacterial pathogens. Front Microbiol. 2014;5:442.

33. Allen RC, Pfrunder-Cardozo KR, Meinel D, Egli A, Hall AR. Associations among antibiotic and phage resistance phenotypes in natural and clinical Escherichia coli isolates. mBio. 2017;8(5):e01341.

34. Hofer B, Ruge M, Dreiseikelmann B. The superinfection exclusion gene ( $\operatorname{sie} A)$ of bacteriophage P22: identification and overexpression of the gene and localization of the gene product. $J$ Bacteriol. 1995;177(11):3080-6.

35. León M, Bastías R. Virulence reduction in bacteriophage resistant bacteria. Front Microbiol. 2015;6(343).

\section{Tables}

Table1. .Primer sequences used in qPCR analysis for my study 


\begin{tabular}{|c|c|c|}
\hline Gene & Molecular function & Primer sequence * \\
\hline \multirow{2}{*}{\multicolumn{2}{|c|}{ 16S rRNAReference gene }} & F: AGGCCTTCGGGTTGTAAAGT \\
\hline & & R: GTTAGCCGGTGCTTCTTCTG \\
\hline \multirow[t]{2}{*}{ btuB } & \multirow[t]{2}{*}{ TonB-dependent vitamin B12 transporter } & F: AGGACACTAGCCCGGATACC \\
\hline & & R: CAGTACATGGCTGGAGTTGG \\
\hline \multirow[t]{2}{*}{ fhuA } & \multirow[t]{2}{*}{ Ferrichrome outer membrane transporter $(\operatorname{ton} A)$} & F: CCAGATGAACGAAAGTAAACAAACAG \\
\hline & & R: GCCGCCGAGAGTAAATACCC \\
\hline \multirow[t]{2}{*}{ fliK } & \multirow[t]{2}{*}{ Flagellar hook-length control } & F:AGCTACTGACCCAACATGGC \\
\hline & & R:GTAAGCGTTTCATCCGTCGC \\
\hline \multirow[t]{2}{*}{$f l j B$} & \multirow[t]{2}{*}{ Flagellin, phage 2 antigen } & F: TGGATGTATCGGGTCTTGATG \\
\hline & & R: CACCAGTAAAGCCACCAATAG \\
\hline \multirow[t]{2}{*}{ ompC } & \multirow[t]{2}{*}{ Outer membrane protein $\mathrm{C}$} & F: TCGCAGCCTGCTGAACCAGAAC \\
\hline & & R: ACGGGTTGCGTTATAGGTCTGAG \\
\hline \multirow[t]{2}{*}{$o m p F$} & \multirow[t]{2}{*}{ Outer membrane protein $\mathrm{F}$} & F: CGGAATTTATTGACGGCAGT \\
\hline & & R: GAGATAAAAAAACAGGACCG \\
\hline \multirow[t]{2}{*}{$r f a L$} & \multirow[t]{2}{*}{ O-antigen ligase } & F: GTGCTTAGCGCCATCTACCT \\
\hline & & R: ACTTCCATTGGCGGTTCAGT \\
\hline \multirow[t]{2}{*}{$\operatorname{sie} A$} & \multirow[t]{2}{*}{ Superinfection exclusion protein A } & F: GCTTCTCCGGGGTATCTTCC \\
\hline & & R: GCCTGTTGTTCTTTGGGTTCC \\
\hline \multirow[t]{2}{*}{$\operatorname{stn}$} & \multirow[t]{2}{*}{ Salmonella enterotoxin } & F: GCCATGCTGTTCGATGAT \\
\hline & & R: GTTACCGATAGCGGGAAAGG \\
\hline \multirow[t]{2}{*}{ tolC } & \multirow[t]{2}{*}{ Multidrug efflux system } & F: GCCCGTGCGCAATATGAT \\
\hline & & R: CCGCGTTATCCAGGTTGTTG \\
\hline
\end{tabular}

${ }^{*} \mathrm{~F}$, forward; R, reverse

Figures 


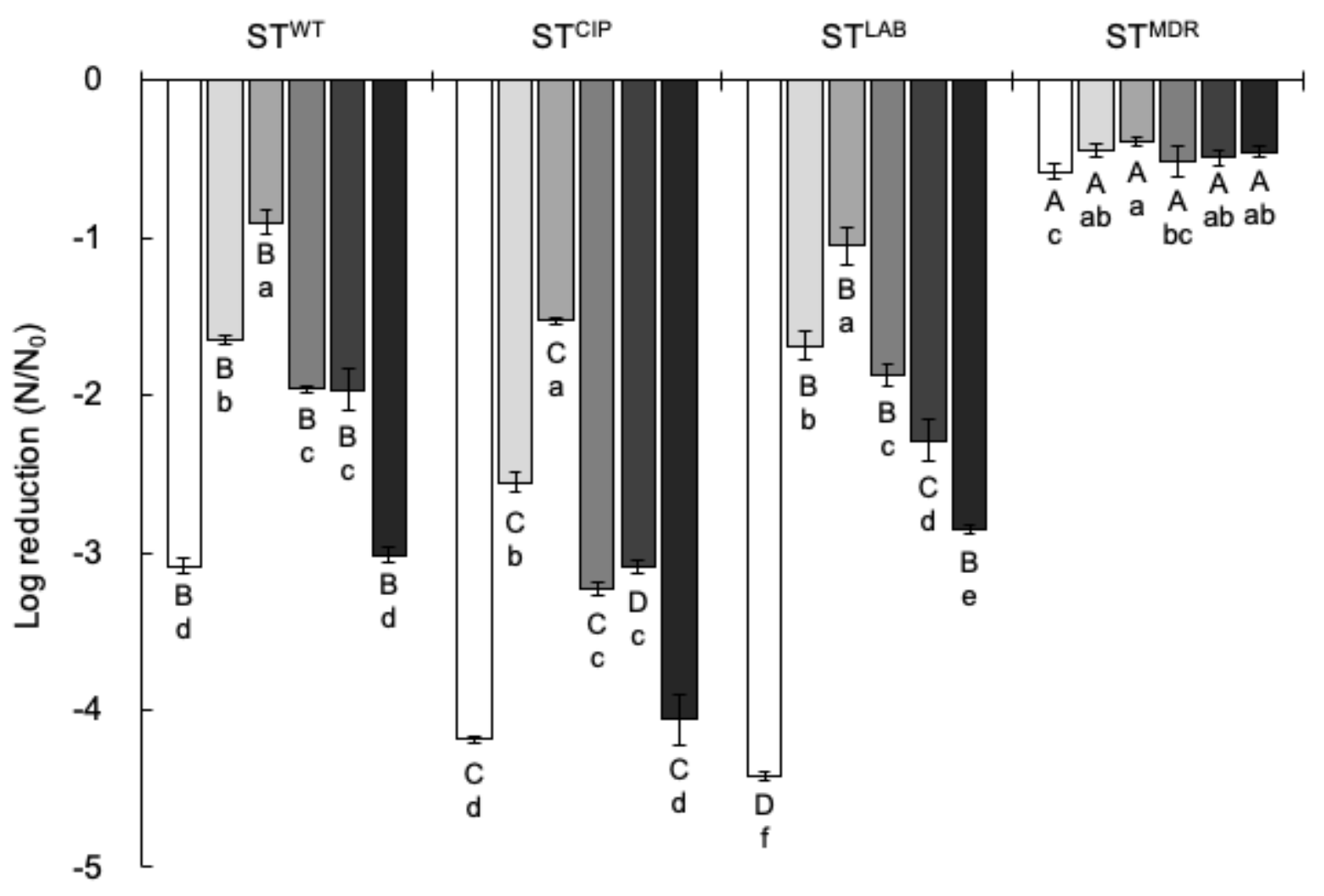

Figure 1

Lytic activity of bacteriophages, P22, P22-B1, PBST-10, PBST-13, PBST-32, and PBST-35, against Salmonella Typhimurium ATCC 19585 (STWT), ciprofloxacin-induced S. Typhimurium ATCC 19585 (STCIP), S. Typhimurium KCCM 40253 (STLAB), and clinically isolated multidrug-resistant S. Typhimurium CCARM 8009 (STMDR). 


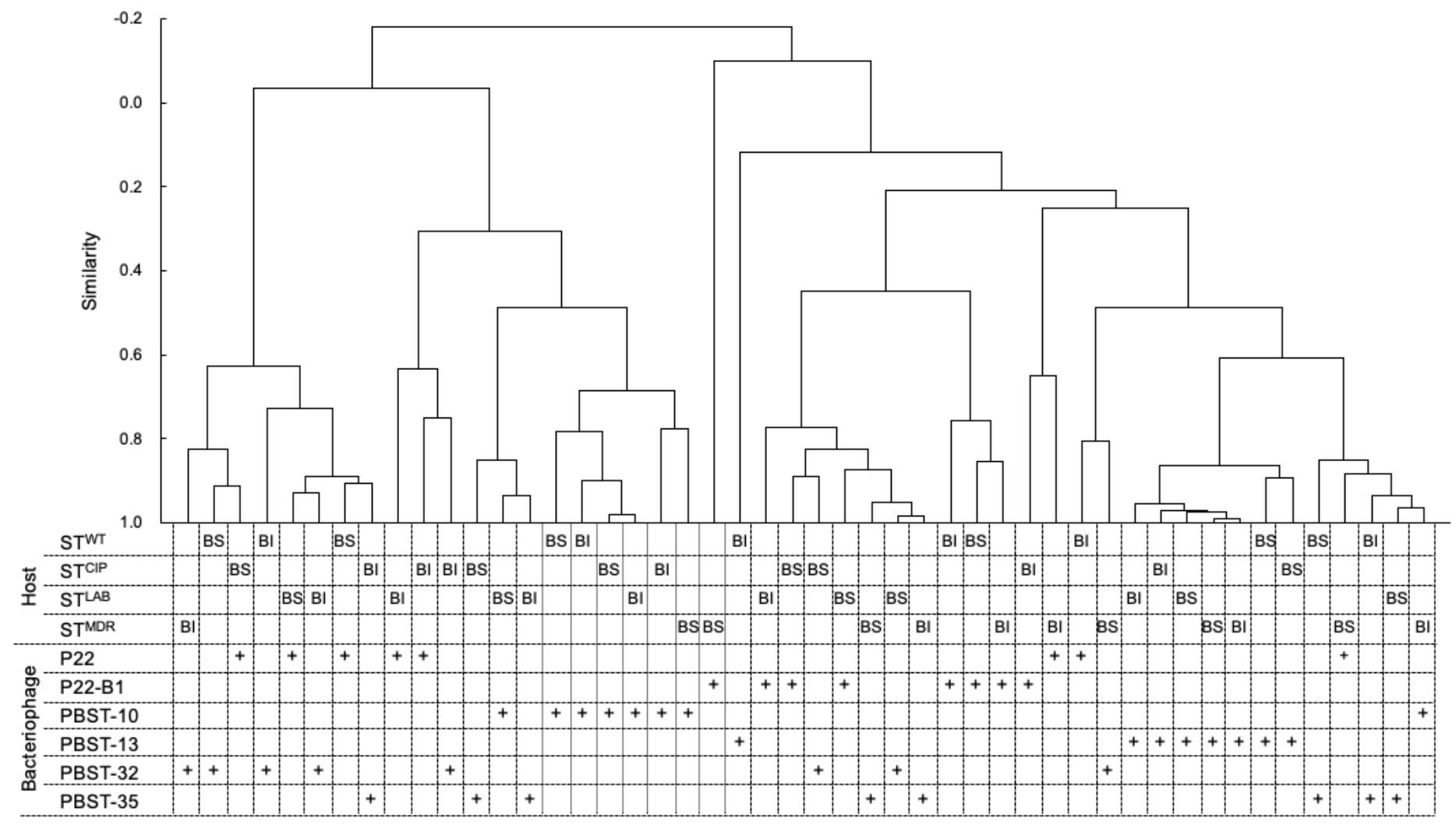

Figure 2

Dendrogram based on the adsorption rates of bacteriophages (P22, P22-B1, PBST-10, PBST-13, PBST-32, and PBST-35; +) to bacteriophage-sensitive (BS) and bacteriophage-insensitive (BI) Salmonella Typhimurium ATCC 19585 (STWT), ciprofloxacin-induced S. Typhimurium ATCC 19585 (STCIP), S. Typhimurium KCCM 40253 (STLAB), and clinically isolated multidrug-resistant S. Typhimurium CCARM 8009 (STMDR). 

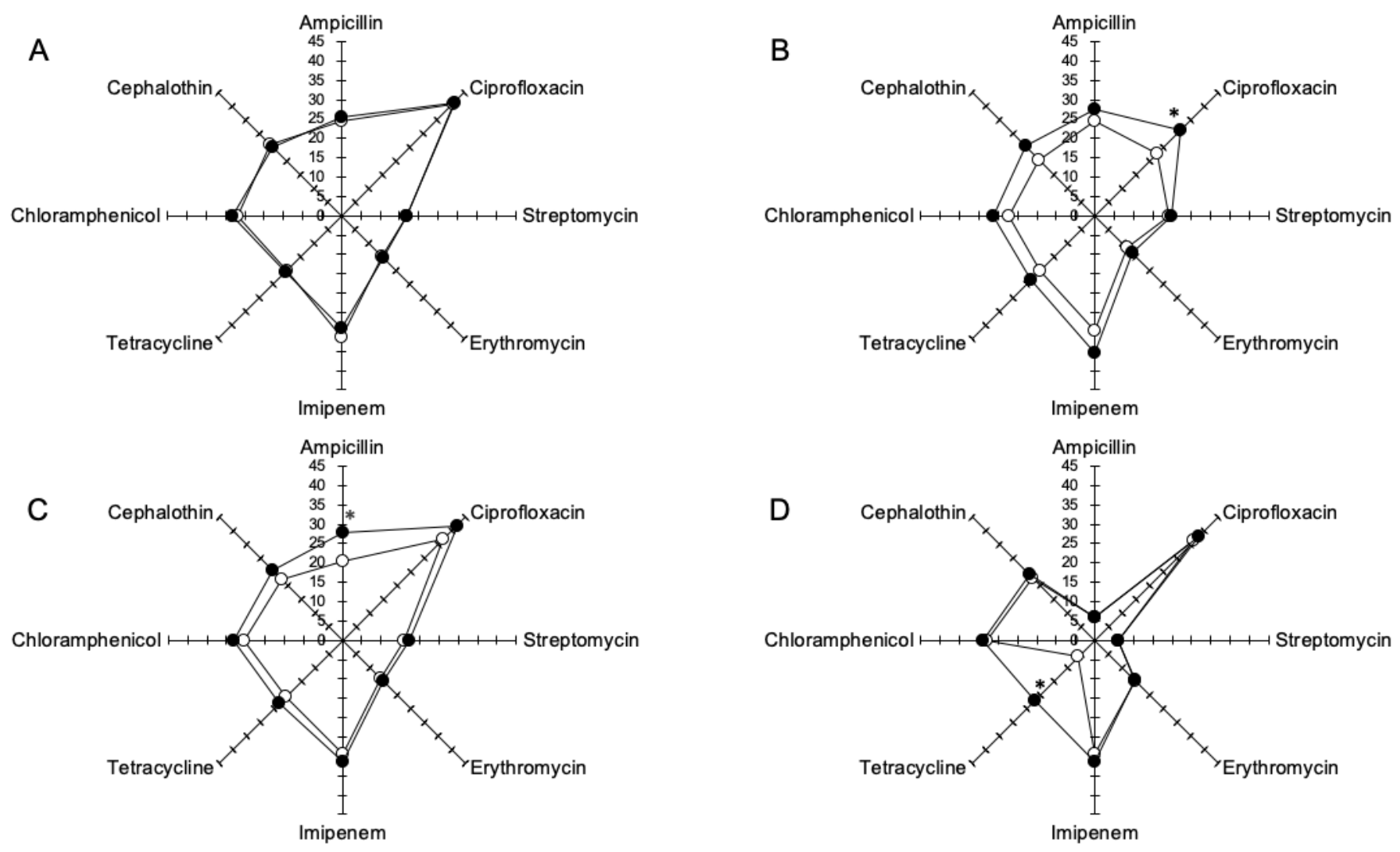

\section{Figure 3}

Radar plot of antibiotic resistance profiles (disk diffusion in $\mathrm{mm}$ ) of bacteriophage-sensitive (BS; $\mathbf{O}$ ) and bacteriophage-insensitive (Bl; O) Salmonella Typhimurium ATCC 19585 (STWT; A), ciprofloxacin-induced S. Typhimurium ATCC 19585 (STCIP; B), S. Typhimurium KCCM 40253 (STLAB; C), and clinically isolated multidrug-resistant S. Typhimurium CCARM 8009 (STMDR; D). * ${ }^{* *}$, and ${ }^{* * *}$ denote significance differences at $p<0.05, p<0.01$, and $p<0.001$, respectively. 


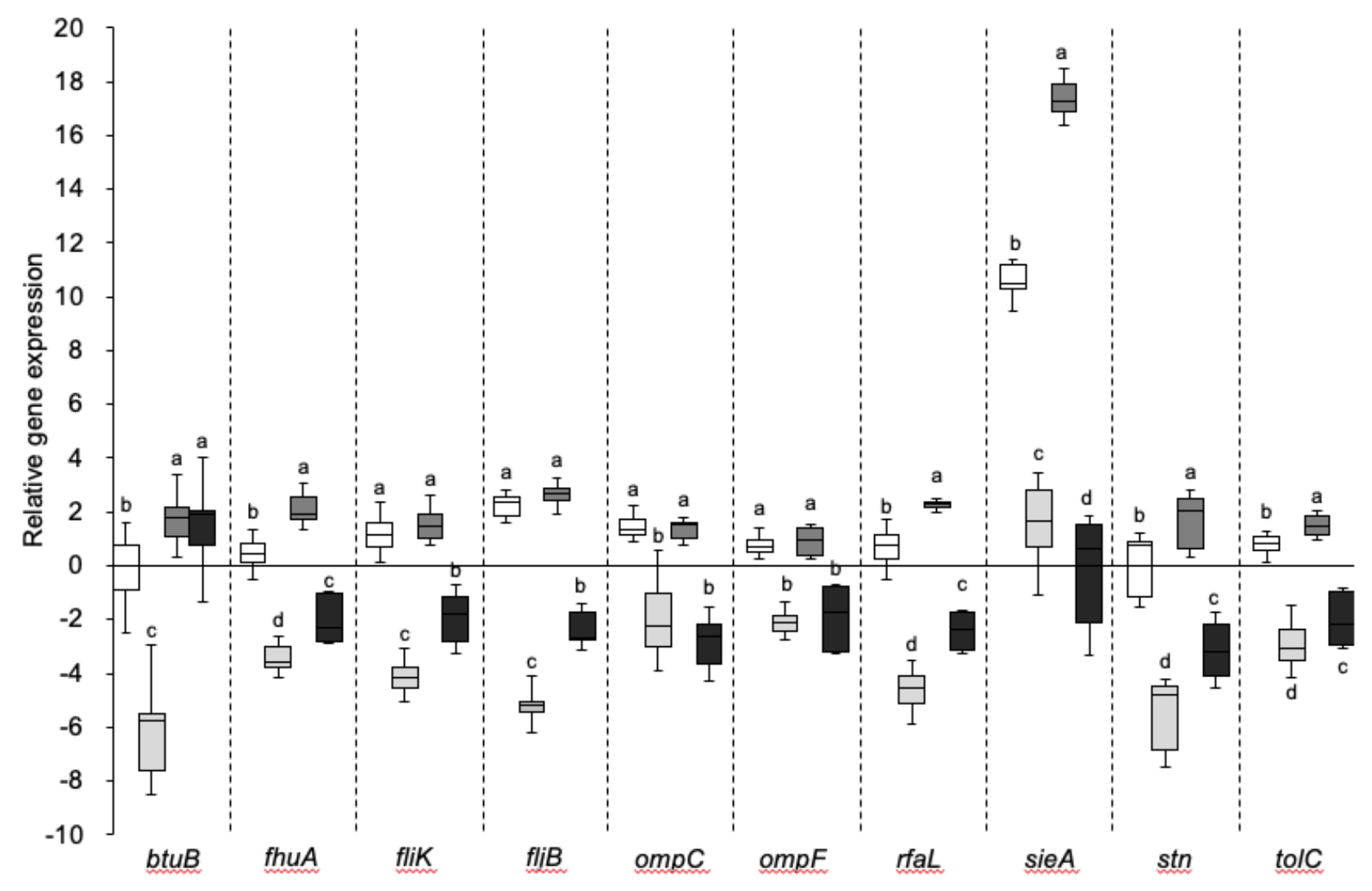

Figure 4

Relative gene expression of bacteriophage-insensitive (BI) Salmonella Typhimurium ATCC 19585 (STWT; $\square$ ), ciprofloxacin-induced S. Typhimurium ATCC 19585 (STCIP; $\boldsymbol{\square}$ ), S. Typhimurium KCCM 40253 $(\mathrm{STLAB} ; \boldsymbol{\square})$, and clinically isolated multidrug-resistant S. Typhimurium CCARM 8009 (STMDR; $\mathbf{\square})$ compared to bacteriophage-sensitive (BS) STWT, STCIP, STLAB, and STMDR, respectively. Different letters $(a-c)$ on the bars within strains are significantly different at $p<0.05$.

\section{Supplementary Files}

This is a list of supplementary files associated with this preprint. Click to download.

- FigureS4.pptx

- FigureS3.pptx

- FigureS2.pptx

- FigureS1.pptx 